\title{
CATECHOLAMINE SECRETION FROM THE ADRENAL GLAND TREATED WTH NEURAMINIDASE, PROTAMINE OR ALKYLATING AGENT
}

\author{
Katsuya IWATSUBO and wao YAMAMOTO \\ Deparment of Pharmacolosy, Osaka University Dental School, Kita-ku, Osaka, Japan
}

Received for publication April 20, 1972

It has been shown that brain gangliosides are concentrated in microsomal fractions and in synaptic membranes $(1-3)$ and that the increased respiratory responses of ccrebral cortex slices to stimulation are inhibited by basic proteins such as histones and protamines and alkylating agents which form covalent linkages in aquoous solutions with carboxylic and other acidic groupings (4, 5). Inhibition of the responses can be restored by polyacidic substances such as gangioside and phosphatidylserine (4). On the other hand a possible role of ganglioside in release of acetyloholine from synaptic vesicles was also shown (6). It may be of interest to determine the intracellular distribution of gangliosides in the alrenal medulta as well as the possible etfect of protamines, neuraminidase and nitrogen mustard of the adrenal medullary secrotion.

Soon after death bovine adienal glonds obtained from the local slaughterhouse were placed on ice, then prepared for medullary ce!l-fractionation and perfusion. The medullae were homogenized in two volumes of $0.25 \mathrm{M}$ sucrose. Fach $0.8 \mathrm{ml}$ of the homogenate was centrifuged in a $0.3-2.3 \mathrm{M}$ sticrose gradient in the $5-\mathrm{ml}$ Spinco preparative ultracentrifuge tubes at $125,000 \times \mathrm{g}$ for 30 min acording to the method of Potter and Axerlod (7). The subchiular fractions were dialized for $18 \mathrm{hr}$ in running tap water, dried in vacuum, and suspended in a homogenizer in $100 \mathrm{ml}$ of chloroform-methanol $(2: 1, \mathrm{v} / \mathrm{v})$. The ganglioside fraction was extracted and estimated as describnd by Burton (8). Succinic dehydrogenase activity was stimated by the method of Slater and Bonner (9). Catecholamines (CA) in the subcellular fractions and the perfusat were assayed by the ethylenediamine condensation mothod (10). Methou of perfusion of bovine adrenal glands was similar to that described by Trifaro et al. (II). CA secretion was evoked by switching perfusion from Locke's solution to Locke's containing $5 \times 10^{-3} \mathrm{M}$ of acetylcholine (ACh), or from Ca-free Locke's solution to Locke's, using perfusion pump. Flor rate was $15 \mathrm{ml} / \mathrm{min}$. For the determination of the cffect of neuraminidase, protamine or nitrogen mustard on the induced CA secretions, the following calculation was used.

Percent of initial secretion : $\begin{gathered}s t_{2}-\mathrm{sp}_{2} \\ s t_{1}-\mathrm{sp}_{2}\end{gathered} \times 100$,

where $s p_{1}$ and $s_{1}$ were initial spontancous release during incubation and the initial stimulated release of $\mathrm{CA}$, respectively, $\mathrm{sp}_{2}$ and $\mathrm{st}_{1}$ were spontaneous and stimulated release of $\mathrm{CA}$ 
TABLE 1. Subcellular distribution of gangliosides in bovine adrenal medulla.

\begin{tabular}{lccc}
\hline \multicolumn{1}{c}{ Tissue fraction } & Gangliosides & Catecholamines & $\begin{array}{c}\text { Succinic } \\
\text { dehydrogenase }\end{array}$ \\
\hline Whole homogenate & 28.7 ( (ag, NANA) & $100(\%)$ & 2.81 (JO.D./min/g) \\
Supernatant & 2.2 & 34.3 & 0.04 \\
Microsomes & 8.6 & 4.5 & 0.04 \\
Mitochondria & 1.8 & 10.0 & 1.18 \\
Chromaffin granules & 7.2 & 29.4 & 0.22 \\
\hline
\end{tabular}

Values of ganglioside content and succinic dehydrogenase activity per gram of fresh adrenal medulla.

TABLE 2. Effect of neuraminidase, protamine and nitrogenmustard on acetylcholineor calcium-induced catecholamine secretion from bovine adrenal gland.

\begin{tabular}{|c|c|c|c|c|}
\hline \multirow[b]{2}{*}{ Treatment } & \multicolumn{2}{|c|}{ ACh-induced CA secretion } & \multicolumn{2}{|c|}{ Ca-induced $\mathrm{CA}$ secretion } \\
\hline & $\begin{array}{l}\text { Pcr cent of initial } \\
\text { secretion* }\end{array}$ & $\mathrm{SP}_{2} / \mathrm{SP}_{1}$ & $\begin{array}{l}\text { Per cent of initial } \\
\text { secretion*** }\end{array}$ & $\mathrm{SP}_{2} / \mathrm{SP}_{1}$ \\
\hline None & $98.5 \pm 8.7$ & $1.1+0.1$ & $112.5 \pm 10.3$ & $0.9 \doteq 0.0$ \\
\hline $\begin{array}{l}\text { Neuraminidase, } 0.24 \mathrm{U} / \mathrm{ml} \text {, } \\
30 \mathrm{~min}\end{array}$ & $154.7=6.7$ & $1.7 \pm 0.2$ & $1 乞 8.7 \pm 9.3$ & $1.0+1.0$ \\
\hline $\begin{array}{l}\text { Protamine, } 0.07 \mathrm{mg} / \mathrm{ml} \text {, } \\
5 \mathrm{~min}\end{array}$ & $\underline{155.2} \pm 10.4$ & $1.7 \pm 0.2$ & $87.6 \pm 13.2$ & $1.0 \pm 1.1$ \\
\hline $\begin{array}{l}\text { Nitrogen mustard, } 4.3 \mathrm{mM} \text {, } \\
15 \text { min }\end{array}$ & $171.5 \pm 27.9$ & $1.6 \pm 0.3$ & $93.6 \pm 9.6$ & $0.9 \pm 0.1$ \\
\hline
\end{tabular}

Values are means and standard errors of 4 to 5 experiments. Underlined values were different from control value at a $\mathrm{p}<0.05$ by $\mathrm{t}$ o-sample $t$-test.

$*$ Average $\mathrm{st}_{1}$ and $\mathrm{sp}_{1}$ were 16.3 and $3.4(\mu \mathrm{g} / \mathrm{min})$, respectivily. $* *$ Average $\mathrm{st}_{1}$ and $\mathrm{sp}_{1}$ were 5.4 and $3.7(\mu \mathrm{g} / \mathrm{min})$, respectively.

30 min after the initial stimulated secretion, respectively. Test compounds or enzyme were perfused between the initial and the second stimulations. The duration of perfusion and the concentration of the test compounds or enzyme are indicated in the Table 2.

Gangliosides were found in greater concentration in the microsomal fraction (29.9 per cent) and in chromaffin granules (25.0 per cent). CA, used as a marker of chromaffin granules, was the greatest concentration in chromaffin granule except supernatant. Succinic dehydrogenase activity, as a mitochondrial marker, was concentrated in the mitochondrial fraction (Table 1).

ACh $\left(5 \times 10^{-5} \mathrm{M}\right)$ produced a 4.8 (average)-fold stimulation of CA secretion. $\mathrm{Ca}$ reintroduction produced a 1.5 (average)-fold stimulation. ACh induced $\mathrm{CA}$ secretion was potentiated by the treatments of adrenal gland with neuraminidase, protamine or nitrogen mustard under such conditions as indicated in Table 2. Spontaneous CA secretions during incubation were found to be somewhat increased after treatments with the enzyme or the compounds (Table 2). Treatment with a high concentration of protamine (more than 0.2 $\mathrm{mg} / \mathrm{ml}$ ) or nitrogen mustard (more than $15 \mathrm{mM}$ ), however, caused increases in $\mathrm{sp}_{2} / \mathrm{sp}_{1}$ (not illustrated). On the contrary CA induced $\mathrm{Ca}$ secretion was not increased by treatment with ncuraminidase, protamine or nitrogen mustard under such conditions as indicated in Table 2. 
Treatment with protamine caused a decrease in per cent of initial secretion.

The above experiments were done to determine whether acidic components which may be involved in $\mathrm{ACh}$ receptor of chromaffin cells might be disturbed by neuraminidase, protamine or nitrogen mustard. Under the conditions tested in the present experiments, however, $\mathrm{ACh}$ induced $\mathrm{CA}$ secretion was potentiated by the enzyne or the compounds which may effect the acidic components of the cells. Ca inducet $C A$ secretion was not influenced by the enzymes or the compounds. When $\mathrm{Ca}$ is reintroduced it enters the cell and activates the amine extrusion mechanism of intracellular site (12), therefore it appears that neuraminidase or nitrogen mustard do not signifaantly interfere with the intracellular amine cxtrusion mechanism. Acidic components such as gangliosides which may be involved in chromaffin cell mombrane may not be an essential factor in so-called stimulussecretion coupling. It is of interest that $\mathrm{ACh}$ indued CA secretion was rather enhanced by the substances which effect acidic components.

Acknowledgemem: The authors wish to express their gratitude to Dr. M. Oka for helpful suggestions.

\section{REFERENCES}

1) De Robertis, E., Azcurra, J.M. awd Sira Figzir: Brain Res. 8, 45 (1967); 2) Azcurra,

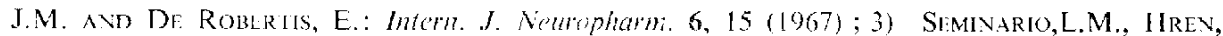
N. A\D Gómic, C.J.: J. Neurochem. 11, 197 (1964); 4) Mcllwals, H.: Biochem. J. 90, 442 (1964) ; 5) Evans, W.If. and Mcllwaiv, H.: J. Newochem. 14, 35 (1967) ; 6) Burton, R. M. AND Howard, R.E.: Anu. Now York Acal. Sci. 144, 411 (1967); 7) POTTER, L.T. AND Axelrod, J.: J. Pharm, exp. Ther, 142, $291(1963) ; 8)$ B!kTON, R.N.: J. Newochem. 10 , 503 (1963):9) Slattr, E.C. AND BONvilR J.., W.D.: Biochem. J. 52. 185 (1952); 10) WeILMarhli:rbe, H. aNd Bont, A.D.: Biochem. J. 51, 311 (1)52); 11) Trujaró, J.M., Poisoner, A.M. And Dolgins, W.W.: Fiochem. Pharm. 16, 2095 (1967); 12) Douglas, W.W.: Mecha-

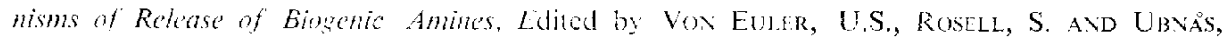
B., p. 267, Pergamon, Oxford (1966) 